\title{
Mismatch Repair Protein
}

National Cancer Institute

\section{Source}

National Cancer Institute. Mismatch Repair Protein. NCI Thesaurus. Code C129420.

A DNA repair protein family that is comprised of the active components of the DNA mismatch repair system. 